\title{
Flight dispersion in field and reproductive status of Scaptocoris castanea Perty (Hemiptera: Cydnidae)
}

Camila Patrícia Ribeiro Souza ${ }^{1}$, Leonardo Morais Turchen² ${ }^{\bowtie}$, Jamile Fernanda Silva Cossolin ${ }^{2}$ \& Mônica Josene Barbosa Pereira ${ }^{1}$

1. Universidade do Estado de Mato Grosso - Campus Tangará da Serra. 2. Universidade Federal de Viçosa.

\section{EntomoBrasilis 12 (1): 44-46 (2019)}

\begin{abstract}
Flight dispersion is an adaptive trait to insects, since that make possible found new habitat with resources adequate to survive and reproduce. This behavior is reported in Scaptocoris castanea Perty (Hemiptera: Cydnidae), however few is known on this issue. Herein, we propose to characterize the flight dispersion of $S$. castanea in field and assess your reproductive status. For this, we conducted samples in soybean and cotton crop by two years (i.e. crop station), where the insects were collected with aerial insect net and sample in soil. We assess presence and/or absence of insect at flight dispersion, sexual rate and reproductive status of females (flight and soil), which was defined as presence of sperm in the spermatheca (i.e. couple female) and number of ovules in ovaries (i.e., full eggs). Our results exhibit that dispersion by flight occurred between March and April (2014) and, February and March (2015), which indicate strong association among flight dispersion and rain period. Besides, we verified that the insects collected during flight exhibit a high proportion of female ( $>0.85$ ), and high reproductive potential from insect at flight and in soil. Therefore, the flight dispersion in $S$. castanea is characterized by occur after mating behavior (presence of sperm in spermatid) and with insect able to colonize new fields (presence of ovules in ovaries).
\end{abstract}

Keywords: Burrower bugs; dispersion; soil-insect-pest; rainy season, reproductive behavior.

\section{Dispersão por voo em campo e status reprodutivo de Scaptocoris castanea Perty} (Hemiptera: Cydnidae)

Resumo. Dispersão por voo é uma característica adaptativa em insetos, pois permite a localização de habitat favoráveis para sobrevivência e reprodução. Tal comportamento é realizado pelo percevejo-castanho, Scaptocoris castanea Perty (Hemiptera: Cydnidae), mas pouca atenção tem sido dada a esta questão. Assim, propõe-se nesta pesquisa caracterizar a dispersão por revoada e status reprodutivo de $S$. castanea em campo. Para isso, realizou-se coletas em áreas de soja e algodão em dois anos (safras). Estas consistiam em captura de insetos em revoadas com rede entomológica e coletas em solo. Avaliou-se a razão sexual dos adultos e o status reprodutivo das fêmeas (revoada e solo), considerando a presença de espermatozoides na espermateca e fêmeas com óvulos nos ovaríolos (óvulos formados). Nossos resultados mostraram que a dispersão por voo ocorreu entre março e abril (2014) e fevereiro e março (2015), o que indica forte associação da dispersão com período da chuva. Além disso, verificou-se que os insetos coletados durante o voo exibiam alta proporção de fêmeas $(>0,85)$ e alto potencial reprodutivo de fêmeas em voo e no solo. Portanto, pode-se concluir que a dispersão de $S$. castanea é caracterizada por ocorrer após comportamento de cópula (presença de esperma na espermateca) e com insetos aptos para colonizar novas áreas (presença de óvulos nos ovaríolos).

Palavras-chave: Comportamento-reprodutivo; inseto-praga-de-solo; percevejos-cavadores; período chuvoso; revoada.

IB urrower bugs (Hemiptera: Cydnidae) are insects of small to medium in size, recognized by the morphological adaptations for digging (SCHWERTNER \& NARDI 2015). The Cydnidae include important insect pest in agriculture, with highlight to Scatptocoris genus in Neotropical region, that are represented by Scaptocoris castanea Perty; Scaptocoris carvalhoi Becker and Scaptocoris buckupi Becker (Hemiptera: Cydnidae) (Grazia et al. 2004; GraZia \& SchwerTNER 2011). These insects (nymphs and adults) feeding roots of crop (e.g., pasture, cotton and soybean), which can provide injuries and compromise plant development, and in extreme situations may cause death (Oliveira \& Malaguido 2004; Pessa et al. 2013).
Researches with focus on biology, ecology and behavior of $S$. castanea are scarce, due to their natural habitat (i.e., subterraneous), which difficulties conducted assays (SCHWERTNER \& NARDI 2015). However, curious behavior traits are reported for burrower bugs, like as: (1) presence of insect in different profundity in soil (following the humidity gradient) (OlIvEIRA \& Malaguido 2004; NARDi et al. 2007); (2) stridulated signals emission (СокL et al. 2006); (3) flight dispersion behavior (Oliveira \& Malaguido 2004; Pereira et al. 2002; Schwertner \& NARDI 2015).

Indeed, the flight dispersion behavior is an important adaptive trait to insects, since that make possible individuals found
Edited by:

Marliton Rocha Barreto

Article History:

Received: 25.v.2018

Accepted: 04.x.2018
Corresponding author:

Leonardo Morais Turchen

\} leonardo1311@gmail.com

(3) http://orcid.org/0000-0003-4089-2675
Funding agencies:

$\leadsto$ FAPEMAT and APROSOJA 
new habitat with resources adequate to survive and reproduce (HARRISON 1980; SCHWERTNER \& NARDI 2015). In addition, research on flight dispersion for insect of soil can provide insight to management of population in field, since that the management strategies as chemical insecticides (seeds or soil) have low efficiency in the control of the insect (ÁviLA et al. 2009). Therefore, herein we propose to characterize the flight dispersion of $S$. castanea in field and assess your reproductive status.

For this, we sampled the insect populations in soybean and cotton fields in Parecis microregion, Mato Grosso, State ( $13^{\circ} 47^{\prime} 28^{\prime \prime} \mathrm{S}$ e $57^{\circ} 33^{\prime} 21.86$ " W) among November (2013) to April (2014) and, November (2014) to March (2015). The insects were collected during flight with entomological net (always when it occurred) and in soil through of excavations of $20 \mathrm{~cm}$ in diameter and 30 $-40 \mathrm{~cm}$ of depth $(\mathrm{n}=30$ hole/sampling) distributed randomly in field. All insects were kept in plastic pots $(145 \mathrm{~mL})$ with soil and conducted to laboratory, where are maintained in controlled environmental conditions at $26{ }^{\circ} \mathrm{C} \pm 2{ }^{\circ} \mathrm{C}$ temperature and, $70 \% \pm 10 \%$ relative humidity. We assess the sexual rate and reproductive status of insects sampled from flight and soil. The reproductive status was defined as presence of sperm in spermatheca and ovules in ovaries, through the procedure conducted by dissection on stereomicroscope (Leica SD6, Leica,
Wetzlar, Germany) with physiological solution. Additionally, the climate data (i.e., precipitation daily) were obtained of INMET meteorological station from Diamantino, MT to correlate with flight dispersion period.

Here, the flight dispersion of $S$. castanea was characterized by occurred between March and April (2014) ( $n=2.042$ specimens) and, February and March (2015) (2.834 specimens), always in crepuscular hours $(5: 30-6: 30 p m)$. In addition, it was observed strong association among flight dispersion period with pluviometry indices, which reveals a long-establishment (2 years) of flight dispersion with rain season finished (Figure 1). Is knowledge that flight dispersion behavior is an important adaptive trait to insect (JOHNSON 1969; HARRISON 1980) and this behavior has been reported for the $S$. castanea by Oliveira \& Malaguido (2004), Pereira et al. (2012) and Schwertner \& NARdi (2015). Besides, according with our observations it is possible hypothesize that the input behavioral to flight dispersion are correlated with hydric saturation of soil (i.e., environment pressure), since that flight dispersion occurred when finished the rain period, however other hypotheses may not be excluded, like as search by new resource (food or habitat) to fixed new population, as suggested by NARDI et al. (2008).

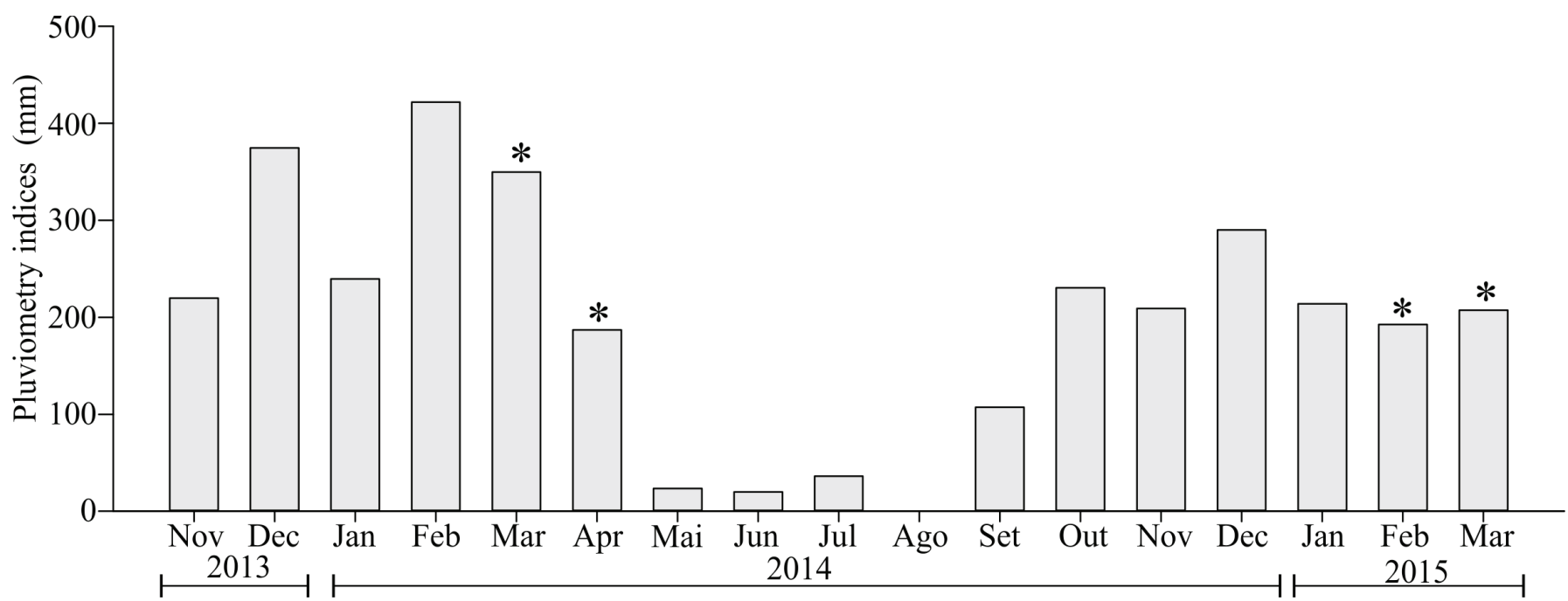

Figure 1. Pluviometry indices ( $\mathrm{mm}$ ) in Parecis microregion and occurrence of flight dispersion by Scaptocoris castanea (indicated by asterisks).

In our study, we reveal a high female rate at flight dispersion, where the insect collected throughout flight dispersion exhibited a sexual rate of 0.83 and 0.87 (March and April, 2014) and; 0.95 and 0.85 (February and March, 2015), which was expected, since that flight dispersion behavior has intuited to colonization of new field, like as suggested by JoHNSON (1969) and NARDI et al. (2008).

We also provide new information on reproductive status of $S$. castanea female at flight dispersion and soil-established. In the females collected throughout flight dispersion, we observed that 100\% (2014) and 98\% (2015) of females contained sperm in spermatheca and, $0 \%$ (2014) and 5.1\% (2015) of females exhibited ovules in ovaries. Besides, we provide a perspective on reproductive status of females in soil (i.e., fertilized and unfertilized females), where we observed that the fecundity of females in soil range of $30-98 \%$ (2014) and $0-40 \%$ of females (2015) (see white bars Figure 2), while the presence of ovule in ovaries range of $0-44 \%$ (2014) and $0-10 \%$ of females (2015) (see number between parentheses in Figure 2).

In other words, it was verified that females collected from flight exhibited high values of sperm in spermatheca and low number of ovules in ovaries, while females collected from soil exhibited high number of ovule in ovaries. Therefore, is remarkable that flight dispersion in $S$. castanea occurred after mating of insects and, likely have function to colonization of new fields. In addition, the high number of ovule in ovaries from female in soil indicate their sexual maturity and suggest that females will start our egg laying (i.e., oviposition) in soil after rain period, which explains the high number of eggs and nymphs in dry period, as observed by Oliveira \& MALAGUido (2004), and Nardi et al. (2007).

In summary, the flight dispersion of $S$. castanea was characterized by exhibit strong relationship with rain season (i.e., end of rain season), predominance of females during the flight and high reproductive potential from insect at flight and in soil. Therefore, we can conclude that the flight dispersion in $S$. castanea occur after mating (presence of sperm in spermatid) and with insect able to colonize new fields (presence of ovules in ovaries). In this context, we can suggest the mass trapping (e.g., light traps or pheromone traps) as a management strategy for the reduction of the population of insect and also to avoid colonization of new fields.

\section{ACKNOWLEDGEMENTS}

The Fundação de Amparo a Pesquisa do Estado de Mato Grosso (FAPEMAT) by finance support, the Associação de produtores de soja e milho (APROSOJA) by Master scholarship; to Fazenda Chapada and Grupo ABC Agrícola by provide field to research 


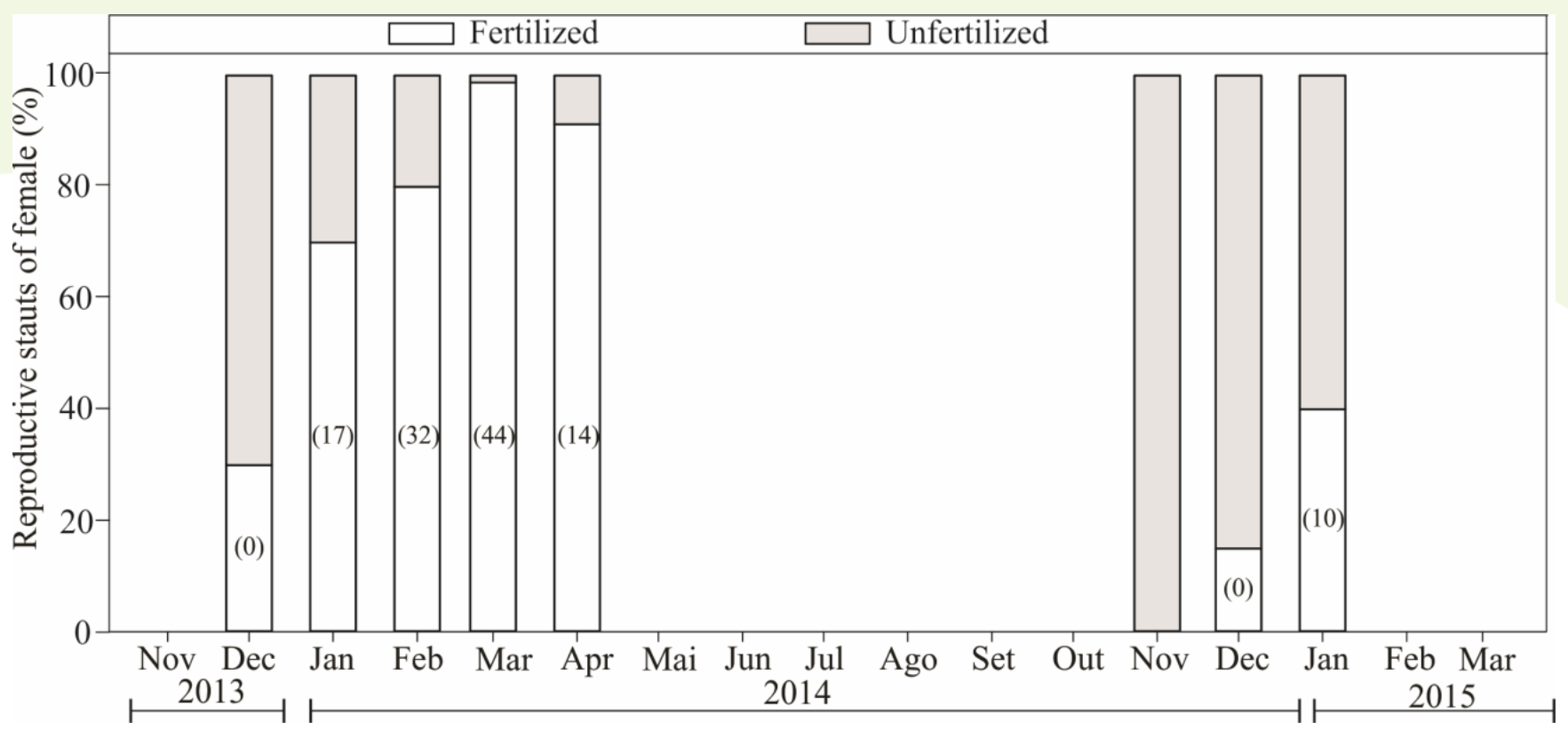

Figure 2. Reproductive status of females of Scaptocoris castanea in soil. Grey bars indicated percentage unfertilized females. White bars indicated percentage fertilized females and the percentage of females with ovule in ovaries are showed between parentheses.

and, to Dr. Cristiano F. Schwertner by confirmed species $S$ castanea.

\section{REFERENCES}

Ávila, C.J., L.M.S. Xavier, \& S.A. Gomez, 2009. Ocorrência, flutuação populacional, distribuição vertical no solo e controle do percevejo castanho da raiz, Scaptocoris ssp. (Hemíptera: Cydnidae) na cultura do algodoeiro, em Mato Grosso do Sul. Dourados: Embrapa Agropecuária Oeste. 36 p.

Cokl, A.J., C. Nardi, J.M.S. Bento, E. Hirose \& A.R. Panizzi, 2006. Transmission of stridulatory signals of the burrower bugs, Scaptocoris castanea and Scaptocoris carvalhoi (Heteroptera: Cydnidae) through the soil and soybean. Physiological Entomology, 31: 371-381. DOI: https://doi.org/10.1111/j.1365-3032.2006.00530.x.

Grazia, J., C.F. Schwertner \& E.J.E. Silva, 2004. Taxonomical and nomenclatural changes in the Scaptocorini (Hemiptera: Cydnidae, Cephalocteinae). Neotropical Entomology, 33: 511-512. DOI: https://doi.org/10.1590/s1519$566 \times 2004000400018$.

Grazia, J. \& C.F. Schwertner, 2011. Checklist of stink bugs (Hemiptera: Heteroptera: Pentatomoidea) from Sao Paulo State, Brazil. Biota Neotropica, 11: 705-716. DOI: https://doi.org/10.1590/s1676-06032011000500034.

Harrison, R.G., 1980. Dispersal Polymorphisms in Insects. Annual Review of Ecology and Systematics, 11: 95-118. DOI: https://doi.org/10.1146/annurev.es.11.110180.000523.

Johnson, C.G., 1969. Migration and dispersal of insects by Light. London, Methuen \& Co Ltd., 763 p.
Nardi, C., P.M. Fernandes, O.D. Rodrigues \& J.M.S. Bento. 2007. Flutuação populacional e distribuição vertical de Scaptocoris carvalhoi Becker (Hemiptera: Cydnidae) em Área de pastagem. Neotropical Entomology, 36: 107-111. DOI: https://doi.org/10.1590/s1519-566x2007000100013.

Nardi, C., P.M. Fernandes \& J.M.S. Bento, 2008. Wing polymorphism and dispersal of Scaptocoris carvalhoi (Hemiptera: Cydnidae). Annals of the Entomological Society of America, 101: 551-557. DOI: https://doi.org/10.1603/00138746(2008)101[551:WPADOS]2.0.CO;2.

Oliveira, L.J. \& A.B. Malaguido, 2004. Flutuação e distribuição da população do percevejo castanho da raiz, Scaptocoris castanea Perty (Hemiptera:Cydnidae) no solo em regiões produtoras de soja. Neotropical Entomology, 33: 283-291. DOI: https://doi.org/10.1590/s1519-566×2004000300002.

Pereira, M.F.A., R.M. Peres \& R.S. Borges, 2012. Population of Scaptocoris castanea Perty (Hemiptera: Cydnidae) in a CropLivestock Integration System. Neotropical Entomology 41: 409-413. DOI: https://doi.org/10.1007/s13744-012-0055-7.

Pessa, L.F.C., E. Oliveira \& R.P. Nogueira, 2013. Scaptocoris castanea (Perty, 1830) (Hemiptera, Cydinidae) em área produtora de Glycine $\max (\mathrm{L}$.$) no município de Primavera$ do Leste, Mato Grosso. Estudo de Biologia, 35: 25-33. DOI: https://doi.org/10.7213/estud.biol.7851.

Schwertner, C.F. \& C. Nardi, 2015. Burrower Bugs (Cydnidae), p. 639-68o. In: Panizzi, A.R. \& J. Grazia (Eds.). True Bugs (Heteroptera) of the Neotropics. Dordrecht, Springer, 901 p. DOI: https://doi.org/10.1007/978-94-017-9861-7 21.

\section{Suggestion citation:}

Souza, C.P.R., L.M. Turchen, J.F.S. Cossolin \& M.J.B. Pereira, 2019. Flight dispersion in field and reproductive status of Scaptocoris castanea Perty (Hemiptera: Cydnidae). EntomoBrasilis, 12 (1): 44-46.

Available on: doi:10.12741/ebrasilis.v12i1.794
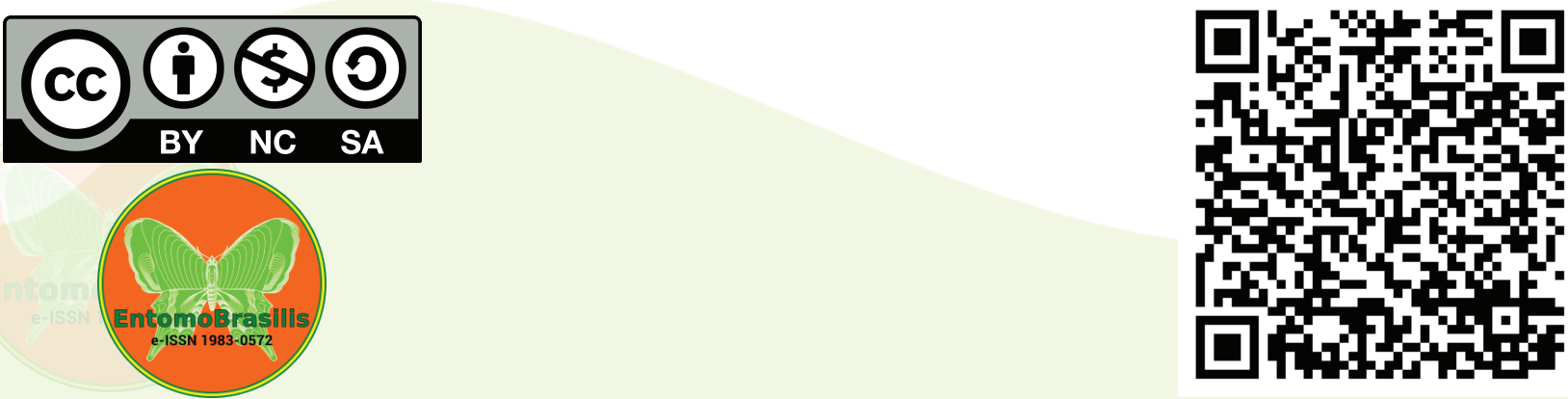